Original Article

\title{
Influence of garlic extract on larval performance and survival of juvenile angelfish Pterophyllum scalare during transport
}

\author{
Influência do extrato de alho no desempenho larval e na sobrevivência durante o \\ transporte de juvenis de acará bandeira Pterophyllum scalare

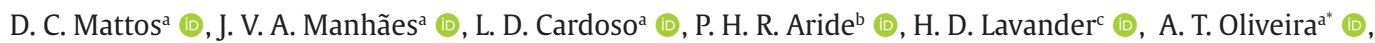 \\ M. C. Radaela (D, R. V. Azevedo ${ }^{a}$ (D) and M. V. Vidal Junior ${ }^{\mathrm{a}}$ (D) \\ aUniversidade Estadual do Norte Fluminense Darcy Ribeiro - UENF, Campos dos Goytacazes, RJ, Brasil \\ 'Instituto Federal de Educação, Ciência e Tecnologia do Amazonas - IFAM, Campus Manaus Centro - CMC, Manaus, AM, Brasil \\ 'Instituto Federal de Educação, Ciência e Tecnologia do Espírito Santo - IFES, Campus Piúma, Piúma, ES, Brasil
}

\begin{abstract}
The objective of this study was to evaluate the properties of garlic as a growth promoter in larvae of angelfish Pterophyllum scalare and its benefits during transport of juveniles of this species. The experiment was conducted in recirculation aquaculture system, consisting of 20 tanks of 40 L equipped with independent water input and output. We used 1,400 larvae distributed among five treatments, with four repetitions, which totaled 20 experimental units. The treatments were $0,50,100,200$, and $400 \mathrm{mg}$ of garlic extract per kilo of feed. The results showed that the inclusion of levels of garlic extract in the feed did not significantly effect the fish's development or their transport. Neither did the inclusion of levels of garlic extract affect the survival of the larvae during the trial period. New research with extracts of higher dosages should be performed to elucidate the effect of garlic extract as a growth promoter.
\end{abstract}

Keywords: larvivulture, transport, fish, allicin, ornamental.

\section{Resumo}

O estudo teve como objetivo avaliar as propriedades do alho como promotor de crescimento em larvas de acará bandeira Pterophyllum scalare e seus benefícios no transporte de juvenis da mesma espécie. 0 experimento foi conduzido em sistema de recirculação composto por 20 aquários de 40 L de volume útil, dotado de entrada e saída de água independentes e teve a duração de 40 dias. 0 delineamento experimental adotado foi o inteiramente casualizado (DIC), com cinco tratamentos e quatro repetições, totalizando 20 unidades experimentais. Foram utilizadas 1.400 larvas de acará bandeira (Pterophyllum scalare) divididas entre os tratamentos. Os tratamentos consistiram em: 0, 50, 100, 200 e $400 \mathrm{mg}$ de extrato de alho por quilo de ração. Os resultados mostraram que não houve efeito significativo dos níveis de inclusão do extrato do alho sobre os índices zootécnicos avaliados e posteriormente no transporte dos juvenis. Também não foi observado influência na sobrevivência das larvas durante o período experimental. Novas pesquisas com dosagens maiores de extratos devem ser realizados para melhor elucidação do efeito do extrato de alho como promotor de crescimento.

Palavras-chave: larvivultura, transporte, peixe, alicina, ornamental.

\section{Introducion}

The ornamental fish trade is globally recognized, and is in great expansion in Brazil (Ladislau et al., 2019; Oliveira et al., 2016). The inclusion of new species in the market, together with improvements in production techniques and implementation of new technologies have contributed to market growth. One of these ornamental fish, which is caught in the wild and produced in captivity, is the angelfish (Pterophyllum scalare). Angelfish can be produced in captivity in different cultivation systems and may be worth up to 10 times more than the specimens caught in the wild. There are several varieties of colors, such as koi, marble, gold, smokey, black lace, and leopard (Ribeiro et al., 2009).

For ornamental fish, the same nutritional requirements are necessary as those provided when rearing fish for human consumption, and may only have the addition of some carotenoids for use in skin pigmentation. However, ornamental fish are subject to much more stressors during marketing than fish for consumption. These stressors are related to capture, packaging, transport and limnological changes arising from these processes, which can contribute to significant losses throughout

*e-mail: adriano.oliveira@ifam.edu.br

Received: October 11, 2020 - Accepted: March 02, 2021 
the production process (Sales and Janssens, 2003). Stress in fish promotes biochemical and physiological changes, which start with the release of catacolamines into the circulation, followed by the release of cortisol, ionic imbalance, changes in hematological parameters, physical exhaustion, loss of organic function, immunosuppression and death (Aride et al., 2016, 2018, 2020; Leal et al., 2020; Wendelaar Bonga, 1997).

Studies have been carried out with plant extracts that have been included in commercial or experimental feed for fish in order to obtain better results in weight gain and immune responses, as well as to combat various diseases caused by a variety of infectious agents, and thus optimize production and avoid losses (Shalaby et al., 2006). Herbal and vegetable additives act as growth promoters and their use has been observed since ancient times. Over time, our knowledge regarding plants has evolved, and systematic isolation and characterization of the active ingredients contained in these plant sources has been achieved (Costa et al., 2007). One of these natural additives for use in growth promotion is garlic extract.

Garlic (Allium sativum) is a plant that originates from Asia and has been used in the therapy of many diseases since ancient times and its cultivation and drug use is known worldwide (Sobrinho and Lopes, 1993). According to Kemper (2008), its uses range from being an appetite stimulant to an antibiotic. Several studies have been carried out with the use of garlic in animal treatment, highlighting use directly in water to control the ectoparasite Trichodina spp in juvenile tilapia (Chitmanat et al., 2005), for parasitic control in sheep, (Sunada et al., 2011), and for the control of bacteria in tilapia (Oreochromis niloticus) (Hussein et al., 2013).

These characteristics make garlic extract a promising additive to be more thoroughly studied in fish nutrition, with the intention of seeking both to minimize losses due to mortality during cultivation and transport, as well as to improve the zootechnical performance of these animals. The objective of this study was to evaluate the properties of garlic as a promoter of growth and survival in angelfish (Pterophyllum scalare) larvae and its benefits in the transport of juveniles of this species.

\section{Materials and Methods}

The experiment was carried out in the aquaculture sector of the Animal Husbandry Research Support Unit of the Center for Agricultural Sciences and Technologies, of the North Fluminense State University Darcy Ribeiro, located in the State Agricultural Technical School Antonio Sarlo, Campos dos Goytacazes, Rio de Janeiro.

The fish used were obtained from four natural spawns of the same age from matrices belonging to the aquaculture sector's collection. The experiment was conducted in a recirculation system composed of 20 aquariums of $40 \mathrm{~L}$ each, and were equipped with independent water inlets and outlets. The system was also composed of a mechanical and biological filter. To maintain the temperature within optimal ranges for the species two thermostats were used.
We used 1,400 angelfish larvae (Pterophyllum scalare) divided into five treatments with four repetitions each, for a total of 20 experiments. The treatments consisted of five isoprotein and isocaloric diets: $\mathrm{T} 1=0 \mathrm{mg} / \mathrm{kg}, \mathrm{T} 2=50 \mathrm{mg}$, $\mathrm{T} 3=100 \mathrm{mg} / \mathrm{kg}, \mathrm{T} 4=200 \mathrm{mg} / \mathrm{kg}, \mathrm{T} 5=400 \mathrm{mg} / \mathrm{kg}$ of garlic extract per kilogram of feed. The experimental replicates were randomly distributed in the recirculation system.

The manufacture of the feed took place using industrial type procedures involving all the basic processes of manufacturing a commercial feed, including the extrusion process. For the ingestion of the feed by the larvae, and later on in their development as juveniles, the feed was ground and sieved in order to allow us to obtain smaller particles. The correction of feed granulometry occurred with the correction of larvae length.

The composition of the feed used for the present study followed the necessary premises for the basic nutrition of fish, with experimental values of garlic extract included. The composition of ingredients can be observed in Table1. The experimental design adopted was completely randomized (RED), with five treatments, four replicates,

Table 1. Composition of ingredients in the experimental feed.

\begin{tabular}{|c|c|}
\hline Ingredients & Crude protein $27 \%$ \\
\hline Fishmeal & $322.8 \mathrm{~g}$ \\
\hline Soy bran & $138.3 \mathrm{~g}$ \\
\hline Cornmeal & $466.5 \mathrm{~g}$ \\
\hline Wheat bran & $20.0 \mathrm{~g}$ \\
\hline Soy bean oil & $50.3 \mathrm{~g}$ \\
\hline Vitamin blend $^{1}$ & $1.0 \mathrm{~g}$ \\
\hline Mineral blend ${ }^{2}$ & $1.0 \mathrm{~g}$ \\
\hline BHT & $0.1 \mathrm{~g}$ \\
\hline Total (g) & $1000 \mathrm{~g}$ \\
\hline \multicolumn{2}{|l|}{ Nutritional Composition } \\
\hline Crude protein ${ }^{4}$ & 271.1g \\
\hline Ether extract ${ }^{4}$ & $93.7 \mathrm{~g}$ \\
\hline Mineral material ${ }^{4}$ & $93.1 \mathrm{~g}$ \\
\hline $\begin{array}{l}\text { Metabolizable energy (kcal } \\
\mathrm{ME} / \mathrm{kg})^{4}\end{array}$ & $3,101 \mathrm{~g}$ \\
\hline Calcium $^{3}$ & $20.4 \mathrm{~g}$ \\
\hline Phosphor $^{3}$ & $10.3 \mathrm{~g}$ \\
\hline Methionine $^{3}$ & 07.1g \\
\hline Methionine + Cystine $^{3}$ & $10.9 \mathrm{~g}$ \\
\hline Lysine $^{3}$ & $20.2 \mathrm{~g}$ \\
\hline Tryptophan $^{3}$ & $03.6 \mathrm{~g}$ \\
\hline Arginine $^{3}$ & $18.7 \mathrm{~g}$ \\
\hline
\end{tabular}

1 - Rovimix Aves initial (Roche): guaranteed levels per $\mathrm{kg}$ of product: vitamins A-12,000 IU; D3 - 2,500 IU; E - 30,000 IU; B1 - 2.0 G; B6 - 3.0 g; Calcium pantothenic - $10.0 \mathrm{~g}$; Choline Chloride $-100.0 \mathrm{~g}$; Butylated Hydroxytoluene (BHT) - 5.0 g; B12 - 15,000 mcg; Olaquindox - 5.0 g; Selenium - $0.120 \mathrm{~g} ; 2$ - Roligomix Aves (Roche): Guaranteed levels per kg of the product: manganese - 160.0; Iron - $100.0 \mathrm{~g}$; zinc - $100.0 \mathrm{~g}$; copper - $20.0 \mathrm{~g}$; cobalt $-2.0 \mathrm{~g}$; iodine $-2.0 \mathrm{~g} ; 3$ - Calculated from tabulated data (Rostagno et al., 1983); 4 - Calculated from tabulated data (Vidal Junior et al., 1998). 
totaling 20 experimental units where the variables that were measured directly in the animals were analyzed according to the methodology of mixed models based on the following statistical model:

$$
Y_{i j k}=\mu+\alpha_{i}+a_{j(i)}+e_{k(i j)}
$$

Where $Y_{i j k}$ corresponds to the measurement performed in the $\mathrm{k}$-th larva, inside the $\mathrm{j}$-th aquarium that received the i-th treatment, and $a_{j}(i)$ represents the random effect of the $j$-th aquarium within the i-th treatment, this supposed effect is normally distributed with a mean of 0 and variance $\sigma_{a}^{2}$. The term $e_{k(i j)}$ represents the normal and independently distributed supposed random error, with mean of 0 and variance $\sigma^{2}$. The effect of treatments was tested using the estimate of the variance of $\sigma_{a}^{2}$ as the denominator. The assumption of homoscedasticity for $\sigma_{a}^{2}$ was verified using a simple model containing only one variance for the different treatments and a model containing heterogeneous variances for the different treatments. The Akaike criterion (1974) was then calculated, and corrected for finite samples or AICc (Sugiura, 1978), according to the recommendations of Burnham and Anderson (2004), and took as the best model the one that presented the highest chance of likelihood and the criterion of parsimony for the degree of parameterization of the models. Variables involving concentrations, i.e. specific growth rate and survival, were transformed to fit the normality criterion. The transformed variable, i.e., $Y_{i j k}^{\prime}=2 \operatorname{arc} \sin \sqrt{Y_{i j k}}$, was then submitted to the same model described in Equation 1. In the tables, the concentrations were presented in the original scale, and the operation $\hat{Y}_{i . .}=100\left[\sin \left(\hat{Y}_{i . .}^{\prime} / 2\right)\right]^{2}$ was performed. In both cases, the MIXED procedure of the SAS statistical program was used (Version 9, SAS System Inc., Cary, NC, USA).

The larvae were weighed and measured to obtain the initial weight (IW), height $(\mathrm{H})$, total length (TL) and standard length $(\mathrm{SL})$, with the aid of a precision analytical scale and caliper. After the measurements were divided between the treatments so that the number of fish from each spawning was equal among all repetitions, thus decreasing the effect of genetics on the final result. The total was 70 larvae per replicate. The animals, after biometrics performed at the beginning of the experiment, presented mean values for $\mathrm{IW}=9.7 \pm 0.20 \mathrm{mg} ; \mathrm{H}=3.71 \pm 0.70 \mathrm{~mm} ; \mathrm{TL}=9.86 \pm 0.64 \mathrm{~mm}$; $\mathrm{SL}=7.84 \pm 0.65 \mathrm{~mm}$.

The monitoring of the physico-chemical variables of the water occurred once every day during the length of the experiment, with the temperature, $\mathrm{pH}$ and dissolved oxygen regulated to values within acceptable limits for the species studied.

The feeding of the diets occurred three times a day, ad libtum, at 8:00h, 12:00h and 17:00h. One hour after each meal, the aquariums were siphoned for the withdrawal of the leftover feed to avoid the depreciation of the quality of the physico-chemical variables of the water and to avoid a possible leaching of the garlic extract.

To evaluate the effects of garlic extract in transport, at the end of the experimental period (40 days), six juveniles were taken from each replicate and were stored in packs with $500 \mathrm{ml}$ of water, according to the ratio of two thirds of air to one of water. In the packaging, pure oxygen was not added. The oxygen dissolved in the water in the packages at the time of closing was measured and presented a mean value of $6.8 \mathrm{mg} / \mathrm{L}$, which was considered sufficient for the survival of the juveniles for a satisfactory time. This permitted us to evaluate the effect of the garlic extract diets on transport.

The start time of the experiment was determined as being when the packaging was sealed, and the end was considered when the last animal died. The time of death of all specimens was determined for subsequent statistical analysis. The packages were examined every hour until the last specimen died, in order to establish the total time of possible transport.

After a normality test had been performed, the treatment groups were compared using one-way ANOVA and the Tukey test was used for post-hoc comparison of means at $\mathrm{P}<0.05$.

\section{Results}

During the experimental period, the water temperature was $27.3 \pm 1.13^{\circ} \mathrm{C}$, which is considered within the comfort range for the species. The mean dissolved oxygen level was $3.91 \pm 0.91 \mathrm{mg} / \mathrm{L}$, the mean $\mathrm{pH}$ value was $7.22 \pm 0.87$, which are values considered satisfactory for the species.

Among the treatments evaluated, the one that contained levels of garlic of $200 \mathrm{mg} / \mathrm{kg}$ of feed obtained better performance for final weight (Figure 1), total length (Figure 2), standard length (Figure 3 ) and height (Figure 4), when compared to the other treatments, however differences were not significant $(p>0.05)$. The survival found (Figure 5) as a result of the treatments was higher in the treatment with inclusion of $400 \mathrm{mg} / \mathrm{kg}$ of feed, followed by the control treatment in which there was no inclusion of garlic extract, and the difference among the treatments was not significant (Figure 6) ( $>0.05$ ). This result suggests that no interference was caused by the different levels of garlic extract, since the highest values of zoo technical performance were observed with the highest and lowest level of inclusion of garlic extract respectively.

When we submitted the data to statistical analysis, it was observed that there was no statistically significant difference among the treatments ( $p>0.05$ ) for any of the parameters of zoo technical performance.

\section{Discussion}

Similar results were observed with juvenile tilapia hybrids (Oreochromisniloticus $x$ O. aureous), since Ndong and Fall (2007) evaluated the inclusion of levels of 0, 0.5, and $1 \%$ of raw garlic in experimental feed and also did not observe significant effect of garlic-rich diets on animal performance. However, the same author evaluated the response of the immune system in relation to the different levels of inclusion of garlic and observed a significant effect in the amount of leukocyte, phagocytic activity, and lysosomal activity of animals fed $0.5 \%$ of garlic in the feed. 


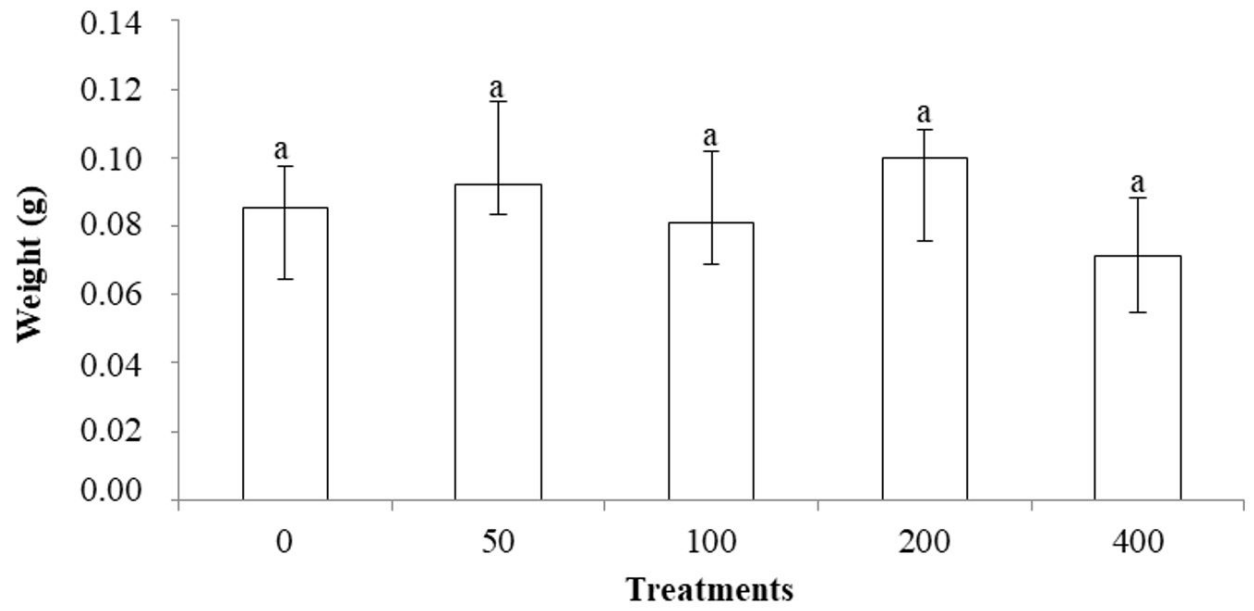

Figure 1. Weight of angelfish after 40 days of treatment with garlic extract.'

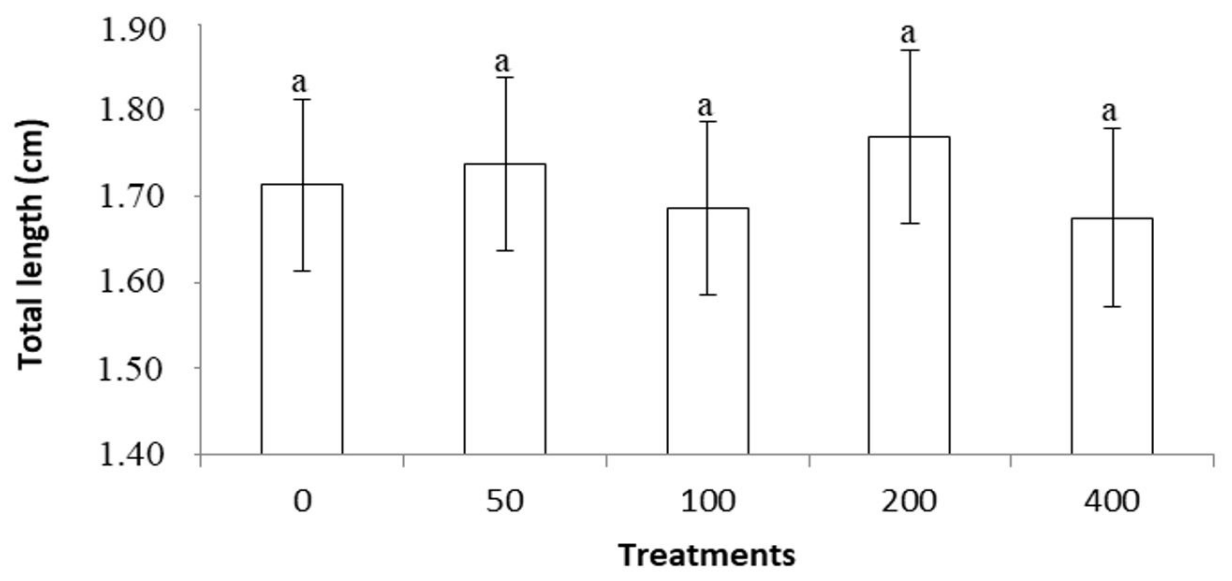

Figure 2. Total length of angelfish after 40 days of treatment with garlic extract.

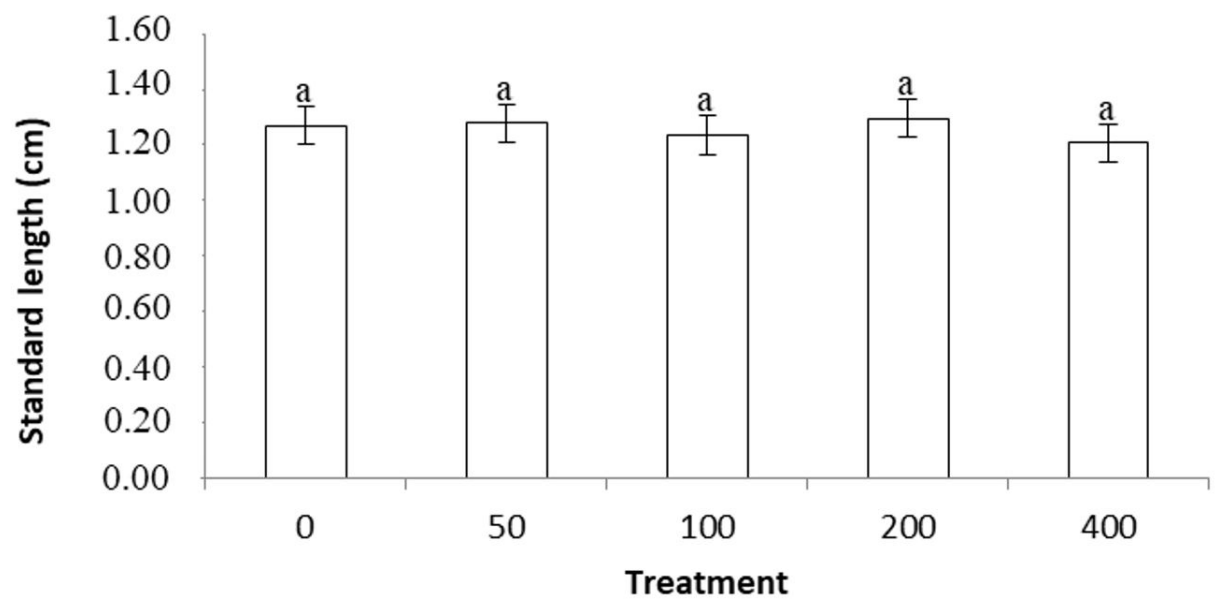

Figure 3. Standard length of angelfish after 40 days of treatment with garlic extract. 


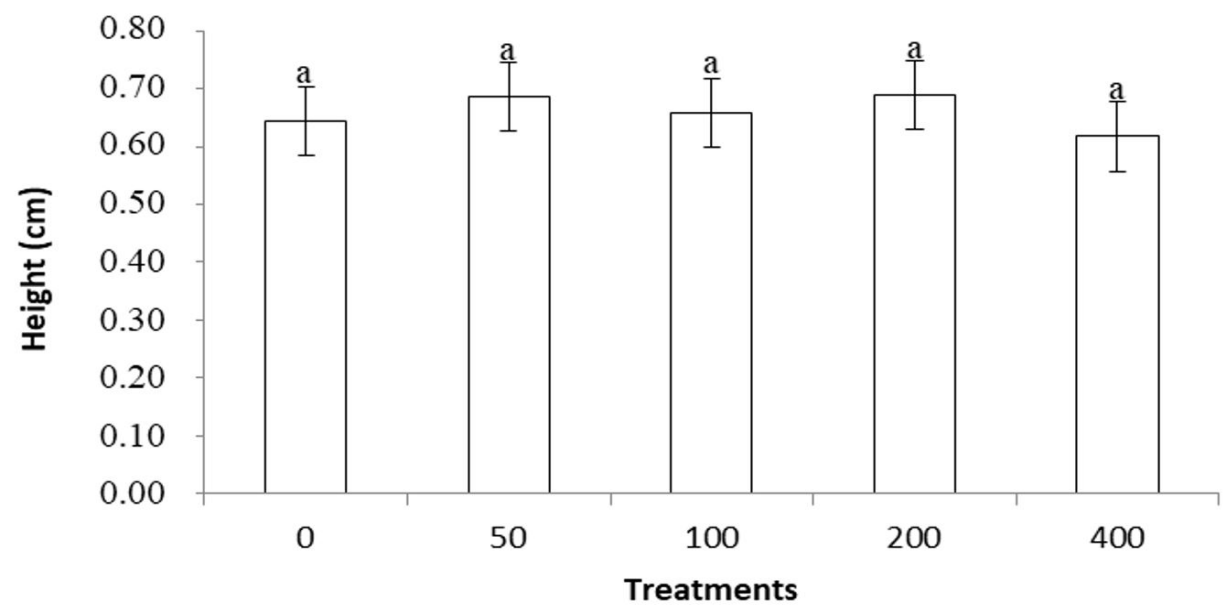

Figure 4. Height of angelfish after 40 days of treatment with garlic extract.

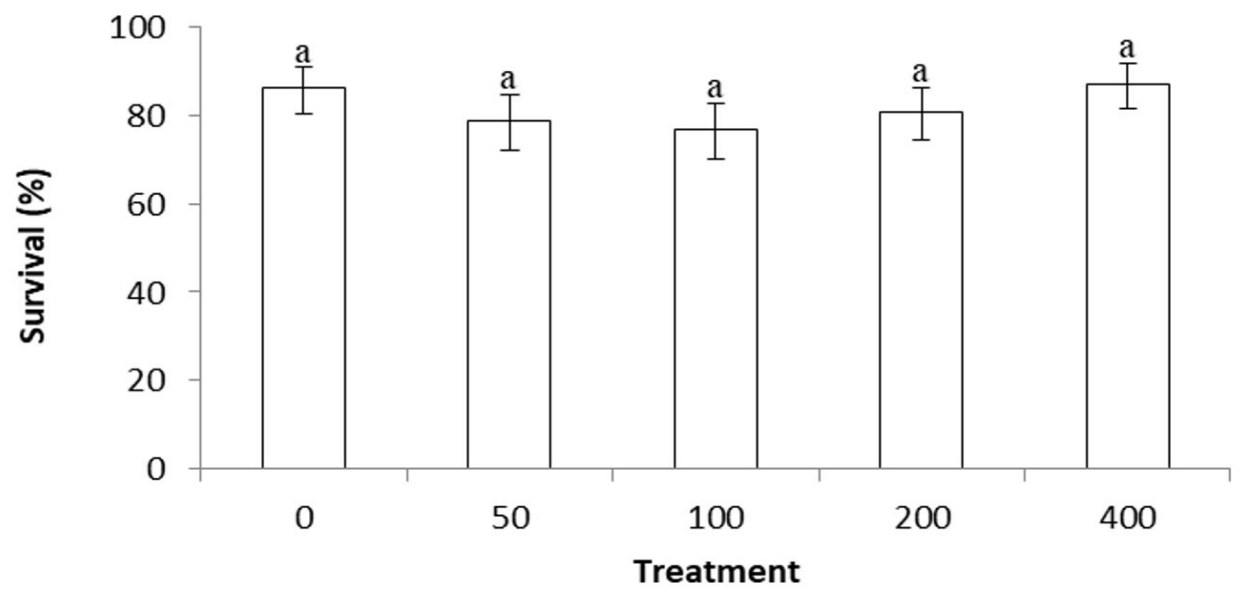

Figure 5. Survival of angelfish after 40 days of treatment with garlic extract.

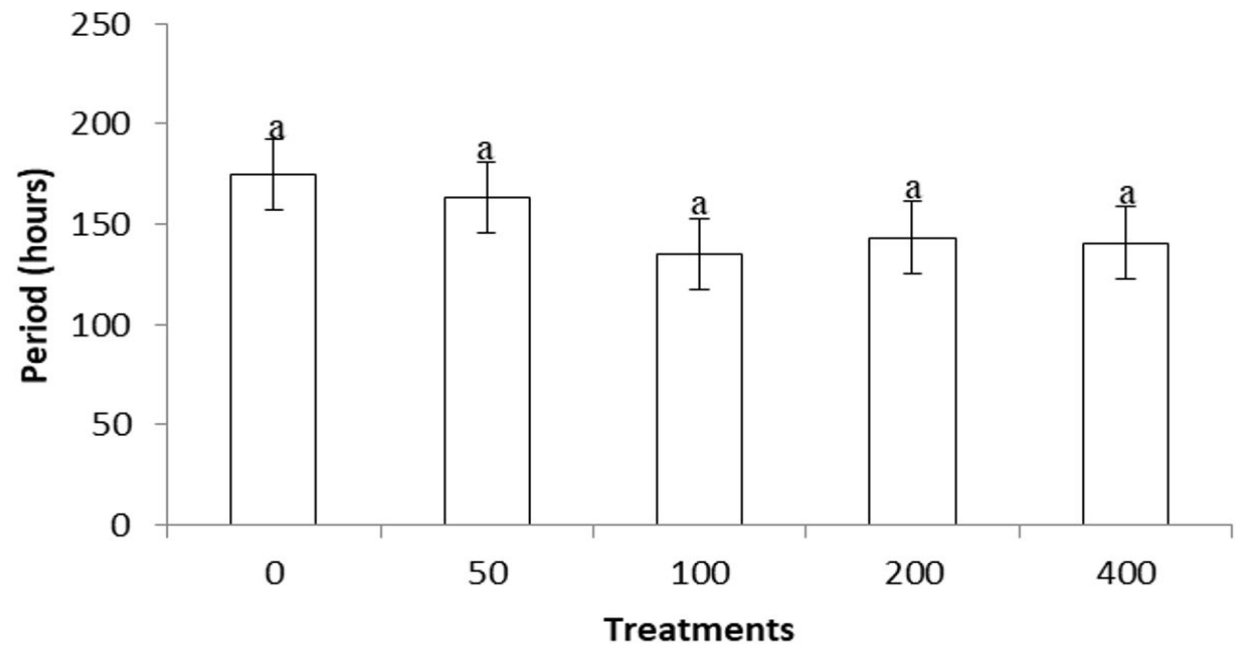

Figure 6. Hours of care between treatments after the start of transport. 
The non-observation of significant difference among treatments may have been influenced by the absence of pathogenic organisms and stressors throughout the experimental period, considering that some of the actions of allicin in the animal's organism is the action against pathogens and immunostimulants (Butolo, 2010). As the cultivation system had strict control of the physico-chemical variables of the water throughout the experimental period, which kept them within comfortable limits for the studied species, it may have contributed to a possible absence of a significant effect of garlic extract on the performance and survival of the larvae.

Marchiori (2005) concluded that there is an immediate need for consumption immediately after preparation with regard to garlic and its beneficial properties, and without the action of heat or any other type of heat treatment, which greatly decreases the concentrations of the sulfide phytochemicals in question. Since the experimental feed was processed and extruded with the presence of heat in the process, substances that could be beneficial to fish performance may have been inactivated or have had reduced action, resulting in non-significant differences among treatments.

Although no positive values for performance were observed in this study, other authors have demonstrated positive results for the use of garlic in fish performance. Shalaby et al. (2006) observed a positive result in the performance of juvenile tilapia, where levels of 1,2,3 and $4 \%$ of garlic extract were included in an experimental feed. It was observed that the treatment in which $3 \%$ of garlic extract was included had better results than the control treatment, both in relation to performance and survival.

Studies that showed a positive effect of the inclusion of garlic in the diet were performed with inclusion values that were higher than those tested in the present study. Low inclusion values may have been one of the factors that contributed to the non-significant result among treatments for zootechnical performance, thus requiring more studies focused on the dosage of the garlic extract.

The total transport time values were $174.58 \mathrm{~h}$ for the inclusion level of $0 \mathrm{mg}, 163.25 \mathrm{~h}$ for $50 \mathrm{mg}, 134.71 \mathrm{~h}$ for $100 \mathrm{mg}, 143.17 \mathrm{~h}$ for $200 \mathrm{mg}$ and $140.57 \mathrm{~h}$ for $400 \mathrm{mg}$. After the data were submitted to statistical analysis, statistical significance was observed among the treatments evaluated. The treatments where the diet contained a lower level of inclusion presented greater total transport time, as can be seen in the chart below.

This result may have been influenced by the bio stimulator characteristic of garlic extract (Kemper, 2008), in which it is recommended that the rate of oxygen use is higher at higher levels of inclusion. This becomes negative for good practices of fish transport, where one of the priorities is the reduction of the metabolic frequency of the fish. This can be either by using anesthetics or decreasing the temperature, for example, and allow a slow reduction of dissolved oxygen and reduction in the volume of excrement in water, which in a confined environment can become lethal to fish (Gomes et al., 2001; Carneiro and Urbinati, 2001; Inoue et al., 2002). However, the results obtained contradict the hypothesis that fish fed with higher levels of garlic extract could present a better response to stress conditions arising from transport, due to a possibly improved immune response, in view of the immunostimulating properties of allicin, as suggested by Butolo (2010).

It is possible to conclude that the levels of $0,50,100$, 200 and $400 \mathrm{mg} / \mathrm{kg}$ of garlic extract included in extruded feed were not satisfactory for the improvement of the zootechnical parameters of angelfish larvae. Regarding transport, the inclusion of garlic extract showed no benefits, and the use of it in animal feed in the pre-transport period is thus not recommended. Thus, additional research is needed with other ingredients that promote benefits in the pre-transport of angelfish larvae.

\section{Acknowledgmens}

A. T. Oliveira is CNPq/Brazil research fellows.

\section{References}

ARIDE, P.H.R., OLIVEIRA, A.M., BATISTA, R.B., FERREIRA, M.S., PANTOJA-LIMA, J., LADISLAU, D.S., CASTRO, P.D.S. and OLIVEIRA, A.T., 2018. Changes on physiological parameters of tambaqui (Colossoma macropomum) fed with diets supplemented with Amazonian fruit Camu camu (Myrciaria dubia). Brazilian Journal of Biology = Revista Brasileira de Biologia, vol. 78, no. 2, pp. 360-367. http://dx.doi.org/10.1590/1519-6984.169442. PMid:28954015.

ARIDE, P.H.R., OLIVEIRA, A.M., FERREIRA, M.S., LIEBL, A.R.S., COMASSETTO, L.E., LADISLAU, D.S., BASSUL, L.A., SILVA, B.R., MATTOS, D.C., LAVANDER, H.D., SOUZA, A.B., POLESE, M.F., RIBEIRO, M.W.S., CASTRO, P.D.S. and OLIVEIRA, A.T., 2020. Growth and hematological responses of tambaqui, Colossoma macropomum fed different levels of rice, Oryza spp. Brazilian Journal of Biology = Revista Brasileira de Biologia, vol. 81, no. 4, pp. 1-7. http://dx.doi.org/10.1590/1519-6984.232560. PMid:33053132.

ARIDE, P.H.R., OLIVEIRA, A.T., OLIVEIRA, A.M., FERREIRA, M.S., BAPTISTA, R.B., SANTOS, S.M. and PANTOJA-LIMA, J., 2016. Growth and hematological responses of tambaqui fed different amounts of cassava (Manihot esculenta). Arquivo Brasileiro de Medicina Veterinária e Zootecnia, vol. 68, no. 6, pp. 1697-1704. http://dx.doi.org/10.1590/1678-4162-8704.

BURNHAM, K.P. and ANDERSON, D.R., 2004. Multimodel Inference: Understanding AIC and BIC in Model Selection. Sociological Methods E Research, vol. 33, no. 2, pp. 261-304. http://dx.doi. org/10.1177/0049124104268644.

BUTOLO, J.E., 2010. Qualidade de ingredientes na alimentação animal. 2. ed. Campinas: Colégio Brasileiro de Nutrição Animal, 430 p.

CARNEIRO, P.C.F. and URBINATI, E.C., 2001. Salt as a stress response mitigator of matrinxã Brycon cephalus (Günther), during transport. Aquaculture Research, vol. 32, no. 4, pp. 297-304. http://dx.doi.org/10.1046/j.1365-2109.2001.00558.x.

CHITMANAT, C., TONGDONMUAN, K. and NUNSONG, W., 2005. The use of crude extracts from traditional me dicinal plants to eliminate Trichodina spp. in tilapia (Oreochromis niloticus) fingerlings. Song klanakarin Journal Science and Technology. Songkhla, vol. 27, no. 1, pp. 359-364.

COSTA, L.B., TSE, M.L.P. and MIYADA, V.S., 2007. Extratos vegetais como alternativas aos antimicrobianos promotores de crescimento para leitões recém-desmamados. Revista 
Brasileira de Zootecnia, vol. 36, no. 3, pp. 589-595. http://dx.doi. org/10.1590/S1516-35982007000300011.

GOMES, L., CHIPPARI-GOMES, A., LOPES, N., ROUBACH, R. and ARAUJO-LIMA, C., 2001. Efficacy of benzocaine as an anesthetic in juvenile tambaqui Colossoma macropomum. Journal of the World Aquaculture Society, vol. 32, no. 4, pp. 426-431. http:// dx.doi.org/10.1111/j.1749-7345.2001.tb00470.x.

HUSSEIN, M.M.A., HAMDY HASSAN, W. and IBRAHIM MOUSSA, M., 2013. Potential use of allicin (garlic, Allium sativum Limm, essential oil) against fish pathogenic bacteria and it safety for monosex Nile tilapia (Oreochromis niloticus). Journal of Food Agriculture and Environment, vol. 11, no. 1, pp. 696-699. http:// dx.doi.org/10.21608/jvmr.2020.77651.

INOUE, L.A.K.A., SANTOS-NETO, C. and MORAES, G., 2002. Benzocaína como anestésico para juvenis de matrinxã (Brycon cephalus). Boletim Técnico do Cepta, vol. 15, pp. 23-30.

KEMPER, N., 2008. Veterinary antibiotics in the aquatic and terrestrial environment. Ecological Indicators, vol. 8, no. 1, pp. 1-13. http://dx.doi.org/10.1016/j.ecolind.2007.06.002.

LADISLAU, D.S., RIBEIRO, M.W.S., CASTRO, P.D.S., ARIDE, P.H.R., PAIVA, A.J.V., POLESE, M.F., SOUZA, A.B., BASSUL, L.A., LAVANDER, H.D. and OLIVEIRA, A.T., 2019. Ornamental fishing in the region of Barcelos, Amazonas: socioeconomic description and scenario of activity in the view of piabeiros. Brazilian Journal of Biology = Revista Brasileira de Biologia, vol. 80, no. 3, pp. 544-556. http://dx.doi.org/10.1590/1519-6984.215806. PMid:31596358.

LEAL, V.G.B., FREITAS, R.A., HIPY, A.D.S., ALMEIDA, F.F.L., OLIVEIRA, A.T., ARIDE, P.H.R. and PANTOJA-LIMA, J., 2020. Avaliação do desempenho zootécnico de linhagens melhoradas de tambaqui Colossoma macropomum (Cuvier, 1818) na Amazônia central. Revista Ibero-americana de Ciências Ambientais, vol. 11, no. 5, pp. 227-236. http://dx.doi.org/10.6008/CBPC21796858.2020.005.0022.

MARCHIORI, V.F., 2005 [viewed 11 June 2021]. Propriedades Funcionais do Alho (Allium sativum L.) [online]. Available from: www.esalq.usp.br/siesalq/pm/alho_revisado.pdf

NDONG, D. and FALL, J., 2007. The effect of garlic (Allium sativum) on growth and immune responses of hybrid tilapia (Oreochromis niloticus $\times$ Oreochromis aureus). Fishery Biology, vol. 2, pp. 172-201.

OLIVEIRA, A.T., SANTOS, M.Q.C., ARAÚJO, M.L.G., LEMOS, J.R.G., SALES, R.S.A., PANTOJA-LIMA, J., TAVARES-DIAS, M. and MARCON, J.L.,
2016. Hematological parameters of three freshwater stingray species (Chondrichthyes: Potamotrygonidae) in the middle Rio Negro, Amazonas state. Biochemical Systematics and Ecology, vol. 69, pp. 33-40. http://dx.doi.org/10.1016/j.bse.2016.07.002.

RIBEIRO, F.A.S., PRETO, B.L. and FERNANDES, J.B.K., 2009. Sistemas de criação para o acará-bandeira (Pterophyllum scalare). Acta Scientiarum, vol. 30, no. 4, pp. 459-466. http://dx.doi. org/10.4025/actascianimsci.v30i4.685.

ROSTAGNO, H.S., SILVA, D.J. and COSTA, P.M.A., 1983. Composição de alimentos e exigências nutricionais de aves e suínos (Tabelas brasileiras). Viçosa: UFV, $59 \mathrm{p}$.

SALES, J. and JANSSENS, G.P.J., 2003. Nutrient requirements of ornamental fish. Aquatic Living Resources, vol. 16, no. 6, pp. 533-540. http://dx.doi.org/10.1016/j.aquliv.2003.06.001.

SHALABY, A.M., KHATTAB, Y.M. and ABDEL RAHMAN, A.M., 2006. Effects of garlic (Allium sativum) and chloramphenicol on growth performance, physiological parameters and survival of Nile Tilapia (Oreochromis niloticus). The Journal of Venomous Animals and Toxins Including Tropical Diseases, vol. 12, no. 2, pp. 172-201. http://dx.doi.org/10.1590/S1678-91992006000200003.

SOBRINHO, J.A.M. and LOPES, C.A., 1993. A cultura do alho. EMBRAPA - Centro Nacional de Pesquisa de Hortaliças, 50 p.

SUGIURA, N., 1978. Further analysis of the data by Akaike's Information Criterion and the finite corrections. Communications in Statistics. Theory and Methods, vol. A7, no. 1, pp. 13-26. http:// dx.doi.org/10.1080/03610927808827599.

SUNADA, N.S., ORRICO JUNIOR, M.A.P., ORRICO, A.C.A., OLIVEIRA, A.B.M., CENTURION, S.R., LIMA, S.R.N., FERNANDES, A.R.M. and VARGAS JUNIOR, F.M., 2011. Controle parasitario utilizando levamizol, ivermectina e alho desidratado (Allium Sativum) em ovelhas da raça Santa Inês. Agrarian (Dourados), vol. 4, no. 12, pp. 140-145.

VIDALJUNIOR, M.V., DONZELE, J.L., ANDRADE, D.R. and CAMARGO, A.C.S., 1998. Níveis de proteína para tambaqui (Colossoma macropomum, Cuvier 1818), na faixa de 30 a 250 gramas. Brazilian Journal of Animal Science, vol. 27, no. 3, pp. 421-426.

WENDELAAR BONGA, S.E., 1997. The stress response in fish. Physiological Reviews, vol. 77, no. 3, pp. 591-625. http://dx.doi. org/10.1152/physrev.1997.77.3.591. PMid:9234959. 